\title{
KEMAMPUAN ANTAGONIS BAKTERI ENDOFIT ASAL TANAMAN SAGU (Metroxylon spp) DALAM MENEKAN PERTUMBUHAN Rhizoctonia solani Kuhn. SECARA IN VITRO
}

\author{
CH. Leiwakabessy*, Yatni, C. Uruilal, R. E. Ririhena, F. J. Rumalatu \\ . Program Studi Agroteknologi Fakultas Pertanian, Universitas Pattimura \\ Jln. Ir. M. Putuhena, Kampus Poka, Ambon 97233 \\ * Email: chr.leiwakabessy@faperta.unpatti.ac.id
}

\begin{abstract}
ABSTRAK
Bakteri endofit merupakan mikroba yang hidup dalam jaringan tanaman tanpa menimbulkan gejala penyakit. Bakteri endofit berpotensi sebagai salah satu teknik pengendalian penyakit seperti penyakit rebah kecambah (Rhizoctonia solani/R. solani) karena kemampuannya untuk hidup dan mengkolonisasi jaringan internal tanaman. Penelitian ini dilakukan terhadap 19 isolat bakteri endofit dari sagu dengan 5 ulangan. Hasil penelitian menunjukkan bahwa dua isolat endofit yaitu STA2 dan STA13 mampu menekan pertumbuhan patogen $R$. solani dibandingkan dengan kontrol dengan persentase penghambatan masing-masing sebesar 41,86\% dan $16,27 \%$.
\end{abstract}

Kata kunci: Antagonistik, bakteri endofit, Rhizoctonia solani, Metroxlon spp.

\section{ANTAGONISTIC ABILITY OF ENDOPHYTIC BACTERIA FROM ORIGINAL Metroxylon spp IN SUPPRESSING IN VITRO GROWTH OF Rhizoctonia solani Kuhn}

\begin{abstract}
Endophytic bacteria is microbe lives in plant tissues without causing symptoms of disease. The benefit of utilizing endophytic bacteria as a technique for controlling diseases such as sprout ( $R$. solani) has been known due to its ability to live and to colonize plant internal tissues. This study aims to determine the ability of endophytic bacteria from sago to suppress the growth of $R$. solani in vitro. This research was conducted using 19 isolates of endophytic bacteria from sago with 5 replications. The results showed that two endophytic isolates namely STA2 and STA13 were able to suppress the growth of $R$. solani pathogens compared to controls with inhibition percentage of $41.86 \%$ and $16.27 \%$, respectively.
\end{abstract}

Key words: Antagonistic, endophytic bacteria, Rhizoctonia solani, Metroxylon spp.

\section{PENDAHULUAN}

Mikroorganisme merupakan salah satu makhluk hidup penting yang mampu membangun hubungan saling menguntungkan dengan tanaman inangnya (Santoyo et al., 2016). Keterkaitan hubungan dalam sistem biologis di antara sesama mikroorganisme diciptakan untuk mengembangkan mikroba di habitat aslinya. Kebanyakan mikroba tersebut berasal dari kelas organisme mikroskopis yang memberikan keuntungan berbeda bagi tanaman inangnya. Di samping juga dalam menghadapi berbagai macam tekanan biotik dan abiotik (Miliute et al., 2015).

Bakteri endofit adalah salah satu mikroba yang memiliki kemampuan hidup di dalam maupun di luar jaringan tanpa menimbulkan kerugian bagi inangnya. Bakteri endofit asal rhizofer termasuk sebagai pemacu pertumbuhan tanaman. Bakteri ini hidup di dalam jaringan inangnya, baik yang ada di bagian perakaran, batang, daun, buah maupun biji serta mampu mempengaruhi perkembangan inangnya (Chebotar et al., 2015).

Keberadaan endofit sangat dipengaruhi oleh lingkungan habitatnya sendiri, termasuk endofit yang berasal dari tanaman sagu yang mampu memberikan efek positif untuk menekan perkembangan patogen. Kemampuan bakteri endofit telah dibuktikan dari berbagai hasil kajian. Bakteri endofit tidak hanya memacu pertumbuhan tanaman, tetapi juga berperan membantu tanaman terhadap stres lingkungan dan menghasilkan alelopati dalam berkompetisi di antara berbagai spesies tanaman (Cipollini et al., 2012; Mei et al., 2009; Rosenblueth and Martínez-Romero, 2006).

Menurut Compant et al. (2010), eksudat akar dapat membantu proses penetrasi bakteri endofit, quorum sensing, dan meminimalkan kompetisi unsur hara serta kemampuan antagonistiknya. Bakteri endofit B. phytofirmans strain PsJN, adalah model endofit 
dengan kemampuan kolonisasi di bagian rhizofer dan endosfer serta memacu pertumbuhan tanaman pada berbagai jenis inangnya seperti Arabidopsis thaliana, anggur, jagung, rumput gajah, tomat dan gandum (Sessitsch et al., 2005; Tezerji et al., 2015). Aktivitas antibiosis dari bakteri endofit Pantoea aglomerans strain E325 mampu menekan Erwinia amyolovora (Pusey et al., 2011); antagonistik terhadap bakteri endofit Bacillus megaterium BP17 and Curtobacterium luteum TC10 dalam menekan perkembangan nematoda patogen tumbuhan Radopholus similis (Aravind et al., 2009).

Beberapa penelitian sebelumnya telah membuktikan bahwa bakteri endofit dapat digunakan sebagai agens hayati, diantaranya sebagai penghasil senyawa bioaktif untuk proteksi tanaman (Melliawati et al., 2006); pengendali nematoda pelukaan akar pada nilam (Harni dan Ibrahim, 2011); antagonis terhadap patogen hawar beludru pada lada (Wulandari et al., 2012); dan sebagai pengendali hayati penyakit darah pada tanaman pisang (Balosi et al., 2014); serta kombinasi antara bakteri endofit dan asam salisilat sebagai penginduksi ketahanan tanaman padi terhadap penyakit hawar daun bakteri (Leiwakabessy et al., 2018). Namun kajian bakteri endofit asal sagu sebagai agens antagonis belum pernah dilakukan. Dengan demikian penelitian ini bertujuan mendapatkan isolat bakteri endofit asal sagu yang mempunyai kemampuan antagonistik terhadap cendawan patogen Rhizoctonia solani Kuhn secara in vitro.

\section{BAHAN DAN METODE}

Penelitian ini dilaksanakan di Laboratorium Mikrobiologi Fakultas Matematika dan Ilmu Pengetahuan Alam (MIPA) Universitas Pattimura, dan berlangsung dari bulan Desember 2017 sampai Februari 2018. Peralatan yang digunakan dalam penelitian ini antara lain bor gabus, oven, cawan petri, rak tabung reaksi, tabung reaksi, jarum ose, api bunsen, erlenmeyer, autoclave, laminar air flow (LAF), shaker, oven, hot plate, pipet tetes, kertas label, dan timbangan analitik. Bahan yang digunakan antara lain : 20 isolat bakteri endofit asal sagu terpilih, biakan Rhizoctonia solani, media TSA (Triptyc soy agar) 100\%, PDA (Potatoes dextrose agar), NA (nutrient agar), NB (nutrient broth), alkohol 70\%, gliserol 40\%, aquades steril, aluminium foil, plastik wrapping, kapas, tisue, spiritus.

\section{Persiapan suspensi isolasi bakteri endofit dan Rhizoctonia solaniKhun}

Bakteri endofit asal sagu yang diperoleh dari hasil seleksi uji patogenesitas pada benih tembakau ditumbuhkan pada media TSA selama 2 hari, kemudian dipanen dan disuspensikan dengan 7-8 ml akuades steril dalam tabung reaksi, kemudian dihitung kepadatan bakteri sampai diperoleh koloni $10^{8} \mathrm{cfu} / \mathrm{ml}$. Isolat cendawan patogen $R$. solani digoreskan ke media PDA sampai umur biakan 24 jam. Selanjutnya isolat cendawan diamati pertumbuhan koloni patogennya untuk digunakan dalam uji selanjutnya.

\section{Uji Penghambatan Pertumbuhan Rhizoctonia solani oleh Bakteri Endofit}

Uji antagonis bakteri endofit terhadap $R$. solani dilakukan dengan menanam kertas saring dan isolat patogen $R$. solani pada media PDA. Kertas saring yang digunakan untuk uji antagonis sebelumnya direndam dulu dalam suspensi bakteri yang telah dishaker selama 2 menit. Setelah itu kertas saring tersebut diangkat lalu diletakan pada sisi cawan dengan jarak $2 \mathrm{~cm}$, sedangkan isolat $R$. solani diambil dengan cork borer dan ditanam pada sisi yang berseberangan dengan jarak $2 \mathrm{~cm}$. Inkubasi dilakukan selama 48 jam lalu dilakukan pengamatan dan pengukuran terhadap pertumbuhan diameter koloni R.solani yang mengarah ke arah bakteri endofit $\left(\mathrm{R}_{2}\right)$ dan diameter koloni R.solani pada biakan kontrol $\left(\mathrm{R}_{1}\right)$ (Gambar 1).
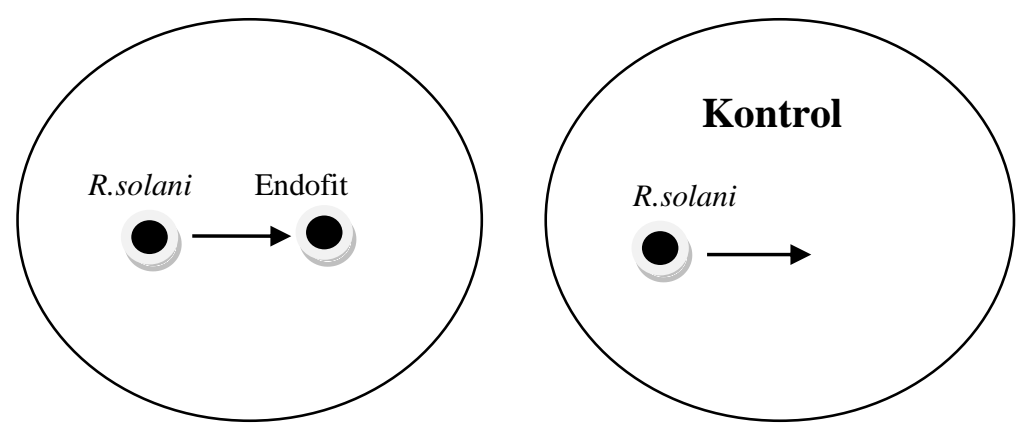

Gambar 1: Uji antagonistik bakteri endofit terhadap Rhizoctonia solani

Berdasarkan hasil pengamatan itu dapat dilakukan perhitungan persentase penghambatan $(\mathrm{PIRG}=$ Percentage Inhibition of Radial Growth $)$ dengan menggunakan rumus yang dikemukakan oleh Skidmore dan Dickinson (1976) sebagai berikut: 


$$
\mathrm{PIRG}=\frac{R 1-R 2}{R 1} \times 100 \%
$$

Keterangan:

$\mathrm{R} 1=$ Diameter koloni $R$.solani pada biakan kontrol

R2=Diameter koloni R.solani yang mengarah pada

koloni antagonis pada Dual Culture Plate.
Indikator bahwa bakteri endofit positif menghambat pertumbuhan isolat patogen yaitu dengan terbentuknya zona bening di sekitar koloni setelah masa inkubasi selama kurang lebih 24-48 jam untuk bakteri.
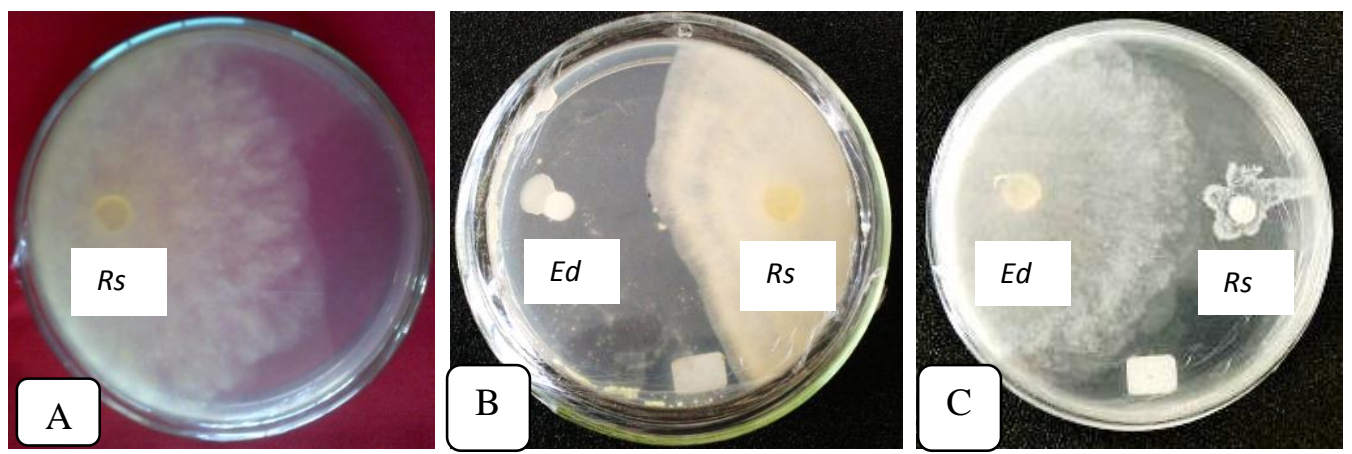

Gambar 2. Uji aktivitas antibiosis bakteri endofit (pengukuran dilakukan pada hari ke-3); Kontrol (A), Isolat bakteri STA2 (B), Isolatbakteri STA13 (C).

Ket : $R s=$ Rhizoctonia solani; $E d=$ Endofit .

\section{HASIL DAN PEMBAHASAN}

\section{Penghambatan Pertumbuhan Rhizoctonia solani Khun oleh Bakteri Endofit asal sagu}

Bakteri endofit dari hasil uji hiper sensitif yang menunjukkan reaksi negative sebanyak 19 isolat kemudian dilakukan uji antibiosis secara in vitro terhadap pathogen $R$. solani. Uji aktivitas antibiosis ini dilakukan untuk mengetahui kemampuan isolat endofit yang didapat dalam menghambat pertumbuhan $R$. solani. Sembilan belas isolat bakteri endofit yang terpilih dilanjutkan pada uji penghambatan pertumbuhan $R$. solani untuk melihat sifat antibiosis endofit tersebut pada cendawan patogen $R$. solani.

Hasil pengujian yang telah dilakukan terhadap 19 isolat bakteri endofit secara in vitro menunjukkan bahwa hanya 2 isolat bakteri endofit yang memiliki kemampuan antibiosis terhadap $R$. solani. Isolat bakteri endofit yang mampu menekan pertumbuhan pathogen $R$. solani keduanya berasal dari kelompok sagu dataran rendah, yaitu isolat STA2 dengan daya hambat sebesar $41,86 \%$ dan STA13 daya hambatnya sebesar 16,27\%. Dari hasil ini dapat dilihat bahwa isolat STA2 memiliki daya hambat yang lebih baik dari STA13 (Gambar 2).

Hasil pengujian in vitro menunjukkan penghambatan pertumbuhan $R$. solani terbesar oleh isolat STA2 dan STA13 dibandingkan dengan yang lainnya. Zona hambat terbentuk disebabkan oleh zat antimikrob yang dihasilkan bakteri. Pembentukan senyawa antimikrob disebabkan berkurangnya nutrisi yang dibutuhkan untuk pertumbuhan sel (Zou et al., 2006). Pada pengujian in vitro isolat-isolat endofit lainnya menghasilkan zona hambat terkecil, hal ini diduga bahwa antimikrob isolat-isolat ini kurang efektif dalam menghambat pertumbuhan $R$. solani. Melliawati et al. (2004) melaporkan bahwa bakteri endofit HL.38B.83 yang berasal dari Tanam Nasional Gunung Halimun mempunyai daya hambat yang sangat luas terhadap pertumbuhan $X$. campestris dan hasil analisis KLT menunjukkan ada dua spot yang berbeda dari standard (media) yang berarti dihasilkan senyawa lain (bioaktif) yang menghambat mikrobia patogen. Mekanisme kerja dari agen pengendali hayati pada umumnya digolongkan sebagai aktivitas kompetisi zat makanan, parasitisme, dan antibiosis (Fravel, 2003). Kemampuan agens hayati mengendalikan patogen berhubungan dengan kemampuan bakteri dalam memproduksi siderofor, $\mathrm{HCN}$, dan senyawa-senyawa metabolit sekunder lainnya.

Berdasarkan hasil penelitian ini menunjukkan bahwa kedua isolat bakteri ini dapat dijadikan sebagai kandidat agens pengendalian hayati (APH) karena memiliki mekanisme antibiosis yang dapat menghambat pertumbuhan patogen. Adanya mekanisme antibiosis dari bakteri endofit dalam menghambat pertumbuhan pathogen disebabkan karena kedua isolate tersebut menghasilkan zat antibiotic. Zat antibiotic merupakan zat yang dimiliki organisme tertentu yang bersifat racun dan dapat menghambat atau menghancurkan organisme lain sehingga keduanya tidak dapat hidup secara bersamaan. Menurut Mohamad et al. (2018), senyawa antibiotik yang dihasilkan oleh senyawa bioaktif Bacillus atrophaeus mampu menekan pertumbuhan cendawan patogen Verticilium dahliae; dan agens penginduksi (elicitor) ketahanan tanaman terhadap penyakit (Borges dan Sandalio, 2015). Kebanyakan penelitian saat ini juga menunjukan bahwa beberapa endofit dapat menghasilkan senyawa-senyawa bioaktif. Sejak diketahui bahwa dinding sel terdiri atas kitin, penelitian tentang kitinase terus berlanjut. Hariprasad et al. (2011) mengatakan bahwa isolat bakteri 
kitinolitik B. Subtilis CRB20 dapat melindungi pembibitan tanaman tomat dari infeksi Fusarium oxysporum melalui enzim kitinase. Kitinase adalah enzim yang dapat mendegradasi kitin yang berada di dalam dinding sel cendawan. Meskipun kitinase adalah enzim yang dapat mendegradasi enzim. Menurut Herdyastuti et al. (2009), mekanisme enzim kitinase sebagai anti jamur terkait dengan adanya kitin pada komponen dinding sel pada tanaman. Kitinase dapat menghidrolisis struktur kitin yang terdapat pada dinding sel jamur, sehingga jamur tidak mampu menginfeksi tanaman. Penelitian tentang bakteri endofit sebagai agens hayati memiliki prospek yang baik untuk dipakai dalam strategi pengendalian hayati, namun isolat-isolat ini perlu dikarakterisasi secara fisiologis dan biokimia, uji in vivo dan in planta khususnya isolat endofit asal sagu yang potensial dikembangkan sebagai agens hayati.

\section{SIMPULAN}

Hasil pengujian secara in vitro terhadap 19 isolat bakteri endofit ditemukan 2 isolat yang berpotensi sebagai agens hayati yaitu STA2 dan STA13 dengan kemampuan penghambatan dengan tingkat penekanan masing-masing sebesar $41,86 \%$ dan $16,27 \%$.

\section{DAFTAR PUSTAKA}

Aravind, R. \& Antony, Dinu \& Eapen, Santhosh \& Aundy, Kumar \& K. Ramana. 2009. Isolation and evaluation of endophytic bacteria against plant parasitic nematodes infesting black pepper (Piper nigrum L.). Indian Journal of Nematology. 39: 211-217.

Balosi, F., I. Lakani, dan J. Panggeso. 2014. Eksplorasi Bakteri Endofit sebagai Agen Pengendalian Hayati terhadap Penyakit Darah pada Tanaman Pisang secara In Vitro. e-J. Arotekbis. 2 (6): 579-586.

Borges, A. A., and L. N. Sandalio. 2015. Induced resistance for plant defense. Frontiers in plant science. 6: 109.

Chebotar, V.K., N.V Malfanova, A.V. Shcherbakov, et al. 2015. Appl Biochem Microbiol. 51: 271. https://doi.org/10.1134/S0003683815030059.

Cipollini, Don \& Rigsby, Chad \& E. Barto. 2012. Microbes as Targets and Mediators of Allelopathy in Plants. Journal of chemical ecology. 38: 714-27.

Compant, S., C. Clément, and A. Sessitscha. 2010. Plant growth-promoting bacteria in the rhizoand endosphere of plants: Their role, colonization, mechanisms involved and prospects for utilization. Soil Biology \& Biochemistry. 42: 669-678.

Fravel, D.R. 2003. Role of Antibiosis In the Biocontrol of Plant Diseases. Annual Review of Phytopathology. 26(1): 75-91.

Hariprasad, P., S. Divakara, and S. Niranjana. 2011. Isolation and characterization of chitinolytic bacteria for the management of Fusarium wilt in tomato. Crop Protect. 30(12):1606-1612.

Harni, R., dan M.S.D. Ibrahim. 2011.Potensi Bakteri Endofit Menginduksi Ketahanan Tanaman Lada Terhadap Infeksi Meloidogyne incognita. Balai Penelitian Tanaman Rempah dan Aneka Tanaman Industri. Jurnal Littri. 17: 118-123.

Herdyastuti, N., T.J. Raharjo, Mudasir and S. Matsjeh. 2009. Chitinase and Chitinolityc Microorganism : Isolation, Characterization and Potential. Indo.J.Chem. 9(1): 37-47.

Leiwakabessy, Ch., M.S. Sinaga, K.H. Mutaqien, Trikoesoemaningtyas, and Giyanto. 2018. The endophytic bacteria, salicylic acid, and their combination as inducers of rice resistance against Xanthomonas oryzae pv. oryzae. AGRIVITA Journal of Agricultural Science. 40(1): 25-35.

Mei, C., and B. Flinn. 2009. The Use of Beneficial Microbial Endophytes for Plant Biomass and Stress Tolerance Improvement. Recent patents on biotechnology.

Melliawati, R., H.I. Sukiman, D.N. Widyaningrum, F. Octavina, E. Sukmawati, and P. Simanjuntak. 2004. Studies on Indonesian endophytic microorganism and their potentials for plant protection of pathogen bacteria. Indonesian Biotechnology Conference. Konsorsium Bioteknologi Indonesia, Sanur, Bali, December 1-3rd, 2004.

Melliawati .R., D.N. Widyaningrum, A.C. Djohan, dan H. Sukiman. 2006. Pengkajian Bakteri Endofit Penghasil Senyawa Bioaktif Untuk Proteksi Tanaman. Pusat Penelitian Bioteknologi, Lembaga Ilmu Pengetahuan Indonesia(LIPI). Biodeversitas. 7: 221-224.

Miliute, I., O. Buzaite, D. Baniulis, and V. Stanys. 2015. Bacterial endophytes in agricultural crops and their role in stress tolerance: a review. Zemdirbyste-Agriculture. 102(4): 465-478.

Mohamad, O., L. Li, J.B. Ma, S. Hatab, L. Xu, J.W. Guo, and W.J. Li. 2018. Evaluation of the Antimicrobial Activity of Endophytic Bacterial Populations From Chinese Traditional Medicinal Plant Licorice and Characterization of the Bioactive Secondary 
Metabolites Produced by Bacillus atrophaeus Against Verticillium dahliae. Frontiers in microbiology. 9: 924.

Pusey, P. \& Stockwell, Virginia \& Reardon, Catherine \& Smits, Theo \& Duffy, Brion. 2011. Antibiosis Activity of Pantoea agglomerans Biocontrol Strain E325 Against Erwinia amylovora on Apple Flower Stigmas. Phytopathology. 101: 1234-1241.

Rosenblueth, M., and E. Martinez-Romero. 2006. Bacterial Endophytes and Their Interactions with Hosts. Molecular Plant-Microbe Interactions. 19: 827-837.

Santoyo, G., G. Moreno-Hagelsieb, M. C. OrozcoMosqueda, and BR. Glick. Plant growthpromoting bacterial endophytes. 2016. Microbiol Res. 183: 92-99.

Sessitsch, A., T. Coenye, A.V. Sturz, P. Van damme, E.A. Barka, J.F. Salles, and J. Nowak. 2005. Burkholderia phytofirmans sp. nov., a novel plant-associated bacterium with plant- beneficial properties. Int $J$ Syst Evol Microbiol. 55(3): 1187-1192.

Skidmore, A.M., and C.H. Dickinson. 1976. Colony interactions and hyphal interference between Septoria nodorum and phylloplane fungi. Trans Brit Mycol Soc. 66: 57-64.

Tezerji S, Raheleh \& Rattei, Thoms \& Sessitsch, Angela \& Trognitz, Friederike \& Mitter, Birgit. 2015. Transcriptome Profiling of the Endophyte Burkholderia phytofirmans PsJN Indicates Sensing of the Plant Environment and Drought Stress. mBio. 6.e00621-15.

Wulandari, H., Zakiyatulyaqin dan Supriyanto. 2012. Isolasi dan pengujian bakteri endofit dari tanaman lada (Piper ningrum L.) sebagai antagonis terhadap patogen hawar beludru (Septobasidium sp.). Jurnal Perkebunan dan Lahan Tropika. 2(2): 23-31.

Zou, Y., Q. Yu, Y.H. Chiu, and X. Bi. 2006. Position effect on the directionality of silencer function in Saccharomyces cerevisiae. Genetics. 174(1): 203-213. 